\title{
A REVIEW OF COALESCED, COLLAPSED-PALEOCAVE SYSTEMS AND ASSOCIATED SUPRASTRATAL DEFORMATION
}

\author{
MEDSEBOJNO ZDRUŽENI PORUŠENI PALEOKRAŠKI JAMSKI \\ SISTEMI IN DEFORMACIJE NAD NJIMI LEŽEČIH PLASTI - \\ PREGLED
}

\author{
Robert G. LOUCKS ${ }^{1}$
}

\begin{abstract}
UDC 551.44

Robert G. Loucks: A Review of Coalesced, Collapsed-Paleocave Systems and Associated Suprastratal Deformation

Coalesced, collapsed-paleocave systems and associated suprastratal deformation appear to be prominent diagenetic/structural features in carbonate sections at/near composite unconformities. The basic architecture of the system can be divided into two sections. The lower karsted section, where high-density cave formation took place, is preserved as massive breccias commonly displaying a rectilinear pattern in map view. The overlying suprastratal deformation section is characterized by large, circular to linear sag structures containing faults and fractures. Regional distribution of coalesced, collapsed-cave systems commonly appears as large-scale (hundreds to thousands of square kilometers in area), rectilinear patterns with areas of concentrated, coalesced breccias separated by relatively undisturbed host rock. This pattern may reflect development of the paleocave system along fracture swarms.

Collapsed-paleocave systems are large, complex features that show broad-scale organization. The complete paleocave system may need seismic data or large, mountain-scale outcrops to define their architecture and distribution.
\end{abstract}

Key Words: Paleocaves, Paleokarst, karst, suprastratal deformation, cave systems.
Izvleček

UDK 551.44

Robert G. Loucks: Medsebojno združeni porušeni paleokraški jamski sistemi in deformacije nad njimi ležečih plasti pregled

Medsebojno združeni porušeni paleokraški jamski sistemi in deformacije nad njimi ležečih plasti predstavljajo izrazite diagenetsko/strukturne oblike karbonatnih zaporedij v bližini sestavljenih geoloških nezveznosti. Osnovno zgradbo posameznega sistema lahko razdelimo na dva dela. Spodnji zakraseli del, kjer je gostota jam velika, je ohranjen v obliki masivnih breč, ki pogosto kažejo v tlorisu vzorec sestavljen iz ravnih odsekov. Za deformirane plasti, ki prekrivajo porušene jamske sisteme, so značilne velike skledaste do škatlaste uleknine, ki jih sekajo prelomi in razpoke. Regionalno gradijo združeni paleokraški jamski sistemi tega tipa vzorec velikega merila (zajemajo območja velika stotine do tisoče kvadratnih kilometrov), sestavljen iz ravnih odsekov in vključuje območja zgoščenih združenih brečastih teles, ločenih z relativno neprizadeto prikamnino. Tak vzorec lahko kaže na razvoj paleokraškega jamskega sistema vzdolž razpoklinskih con. Porušeni paleokraški jamski sistemi predstavljajo velike kompleksne pojave, ki odražajo organiziranost velikega merila. Za opredelitev zgradbe in razprostranjenosti popolnega paleokraškega jamskega sistema teh dimenzij potrebujemo podatke seizmičnih raziskav ali izdanke dimenzij gorovja. Ključne besede: pelokraški jamski sistemi, paleokras, deformacije, jamski sistemi.

\footnotetext{
${ }^{1}$ Bureau of Economic Geology, John A. and Katherine G. Jackson School of Geosciences, The University of Texas at Austin, University Station Box X, Austin, Texas 78713-8924 U.S.A., Fax: 512-471-0140, email: bob.loucks@beg.utexas.edu
} 


\section{INTRODUCTION}

At several composite unconformities in the stratigraphic record, carbonate sections display extensive karsting that leads to multiple development of cave systems (Esteban, 1991). These cave systems underwent extensive collapse and mechanical compaction with burial. Deformation of the overlying strata is associated with burial collapse of the cave system. The effects of this suprastratal deformation can be noted $700+\mathrm{m}$ up section above the karsted interval.

This review will describe the evolution of cave systems during burial and what the characteristics of the cave systems are at different stages of burial. Also the characteristics of suprastratal deformation will be described. Paleocave systems have been investigated by several authors including Lucia $(1968,1995,1996)$, Loucks and Anderson (1980, 1985), Kerans (1988, 1989, 1990), Wilson et al. (1991) Wright et al. (1991), Candelaria and Reed (1992), Loucks and Handford (1992), Lucia et al. (1992), Kerans et al. (1994), Hammes et al. (1996), Mazzullo and Chilingarian (1996), McMechan et al. (1998), Loucks (1999, 2001, 2003), Loucks et al. (2000, 2004), Loucks and Mescher (2001), McMechan et al. (2002), and Combs et al. (2003). The review will mainly synthesize material from these studies.

\section{CLASSIFICATIONS OF CAVE PRODUCTS AND FACIES}

Loucks (1999) and Loucks and Mescher (2001) produced classifications of cave products and cave facies. Loucks (1999) used a ternary diagram (Fig. 1) to show the relationships between crackle breccias, mosaic breccias, chaotic breccias, and cave sediments. Crackle breccias are highly fractured rock, with thin fractures separating the clasts and only minor displacement existing between the clasts. Mosaic breccias show more displacement than crackle breccias, but the clasts can still be fitted back together. Chaotic breccias are com-

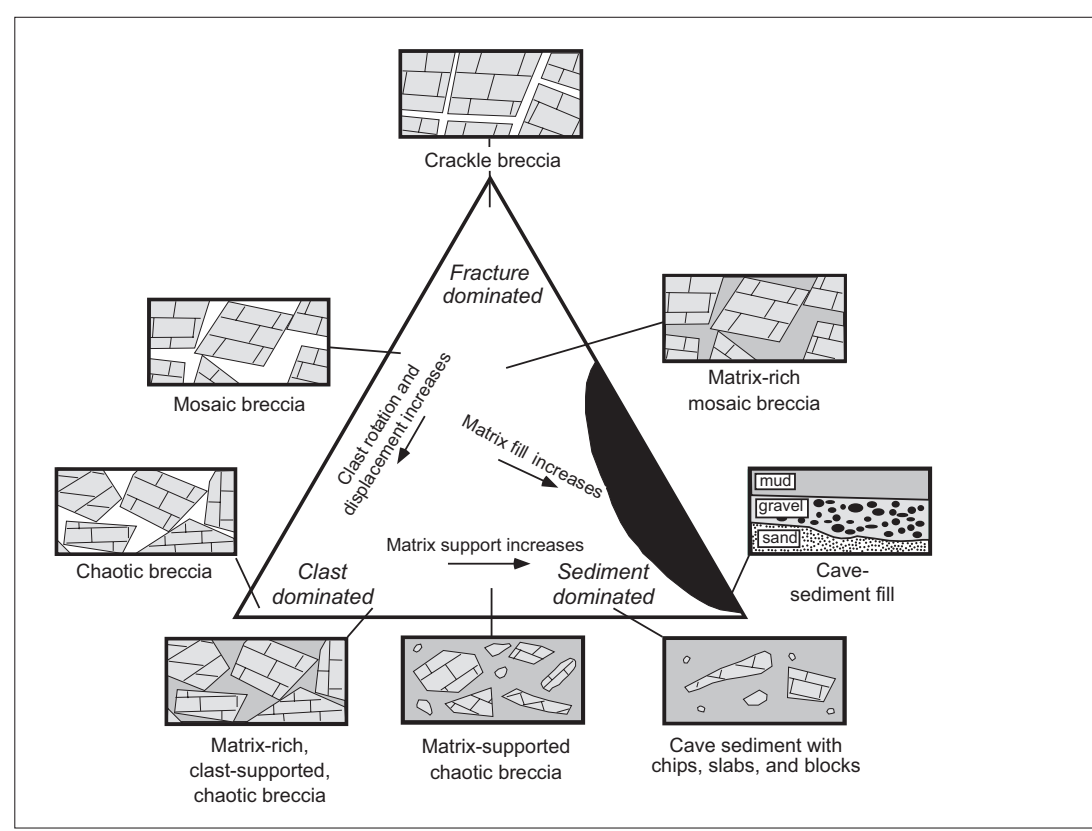

Fig. 1: Cave-sediment fills and breccias can be separated into three end members: crackle breccia, chaotic breccia, and cave-sediment fill. Modified from Loucks (1999) and reprinted by permission of the AAPG whose permission is required for further use." posed of mixtures of clasts that have been transported vertically by collapse or laterally by fluvial or densityflow mechanisms. Clasts show no inherent association with their neighbors. Chaotic breccias grade from matrix-free, clast-supported breccias; through matrix-rich, clast-supported breccias; to matrix-rich, matrix-supported breccias. Cave-sediment fill can consist of any material, texture, or fabric.

Loucks and Mescher (2001) proposed a classification of six common paleocave facies (Fig. 2): (1) Undisturbed strata, which are interpreted as undisturbed host rock. In this facies bedding continuity is excellent for tens of hundreds of meters. (2) Disturbed strata that are disturbed host rock around the collapsed passage. Bedding continuity is high, but it is folded and offset by small faults. It is commonly overprinted by crackle and mosaic brecciation. (3) Highly disturbed strata, which is collapsed host rock adjacent to or immediately above passages. (4) Coarse-clast chaotic breccia that is interpreted as collapsed-breccia cavern fill produced by ceiling and wall collapse. It is characterized by a mass of very poorly sorted, granule- to bouldersized chaotic-breccia clasts approximately 0.3 to $3 \mathrm{~m}$ long that form a ribbon-to tabular-shaped body as much as $15 \mathrm{~m}$ across and hundreds of meters long. It is commonly clast 


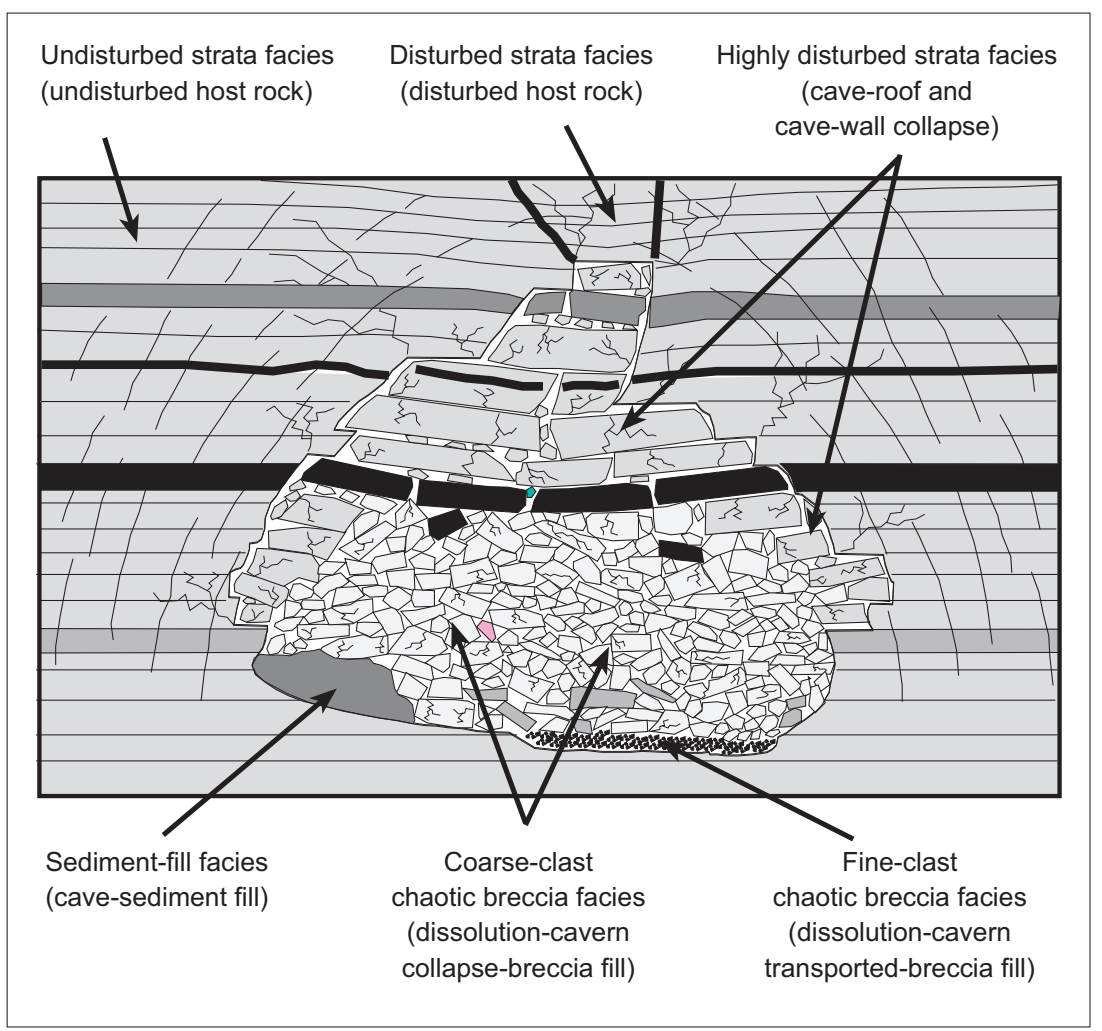

supported, but can contain matrix material. (5) Fine-clast chaotic breccia interpreted as laterally (hydrodynamically) sorted, transportedbreccia cavern fill. Characterized by a mass of clast-supported, moderately sorted, granule- to cobblesized clasts with varying amounts of matrix. Clasts can be imbricated or graded. Resulting bodies are ribbonto tabular-shaped and are as much as $15 \mathrm{~m}$ across and hundreds of meters long. (6) Cave-sediment cavern fill that can be carbonate and/or siliciclastic debris of any texture or fabric and commonly displaying sedimentary structures.

Fig. 2: Six basic cave facies are recognized in a paleocave system and are classified by rock fabrics and structures. Modified from Loucks and Mescher (2001) and reprinted by permission of the AAPG whose permission is required for further use."

\section{EVOLUTION OF CAVE PASSAGES}

Knowledge of the processes by which a modern cave passage forms at the surface and evolves into a col-

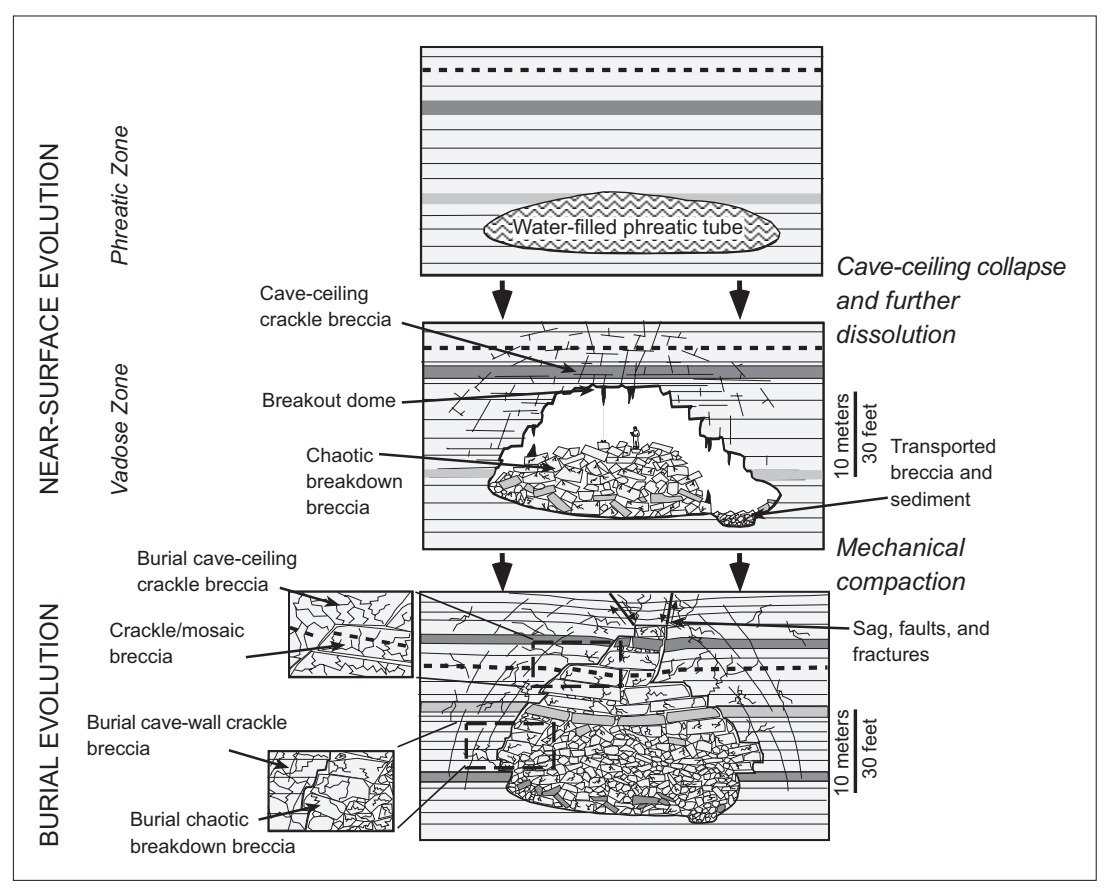

lapsed paleocave passage in the subsurface is necessary to understand the features of paleocave systems. Loucks (1999) described this evolutionary process (Fig. 3), and the review presented here is mainly from that investigation.

A cave passage is a product of near-surface karst processes that include dissolutional excavation of the passage, partial to total breakdown of the passage, and sedimentation in the passage (Fig. 4). During later-burial cave collapse, mechanical compaction takes place.

Fig. 3: Schematic diagram showing evolution of a single cave passage from its formation in the phreatic zone of a nearsurface karst environment to burial in the deeper subsurface. Modified from Loucks (1999) and reprinted by permission of the AAPG whose permission is required for further use." 
Initial passages form in phreatic and/or vadose zones (Fig. 3). Passages are excavated where surface recharge is concentrated by preexisting pore systems, such as bedding planes or fractures (Palmer, 1991), that form a continuous link between groundwater input, such as sinkholes, and groundwater output, such as springs (Ford, 1988). Cave passages are under stress from the weight of

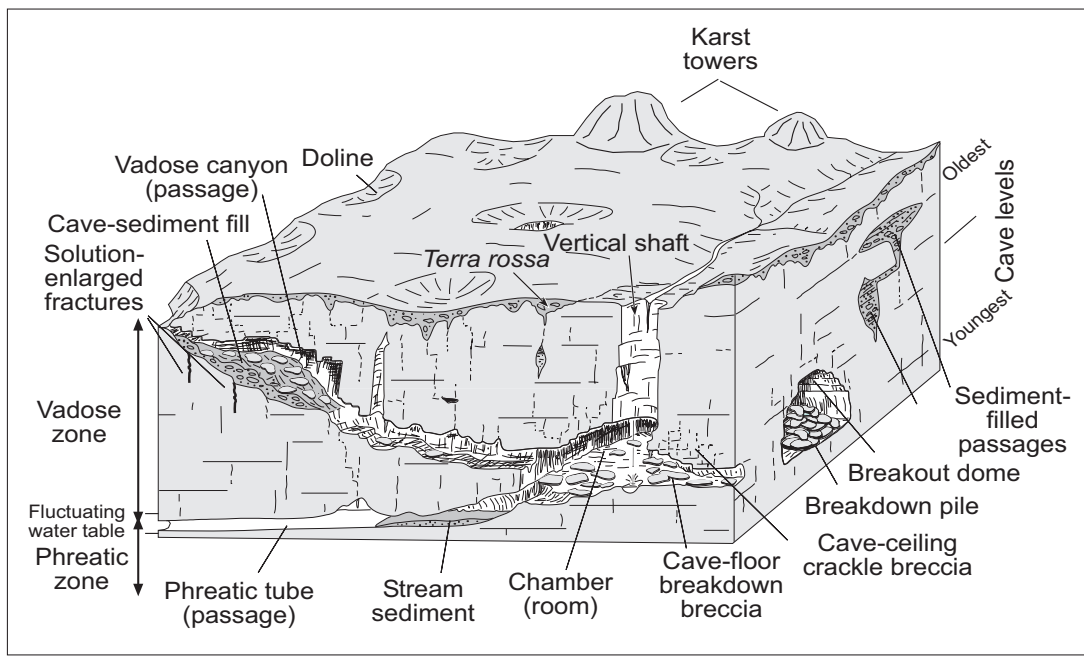

Fig. 4: Block diagram of a near-surface modern karst system. The diagram depicts four levels of cave development (upper-right corner of block model), with some older passages (shallowest) having sediment fill and chaotic breakdown breccias. Modified from Loucks (1999) and reprinted by permission of the AAPG whose permission is required for further use." overlying strata. A tension dome, or zone of maximum shear stress, is induced by the presence of the passage or cavity (White, 1988). Stress is relieved by collapse of the rock mass within the stress zone. This collapse produces chaotic breakdown breccia on the floor of the cave passage (Figs. 3 and 4). The associated stress release around the cavity produces crackle and mosaic breccias in the adjacent host rock.

As cave-bearing strata are buried, extensive mechanical compaction begins, resulting in collapse of the remaining void (Fig. 3). Multiple stages of collapse occur over a broad depth range. Meter-scale bit drops in wells (indication of cavernous pores) are not uncommon down to depths of 2,000 $\mathrm{m}$ and are observed to occur to depths of 3,000 m (Loucks, 1999). The collapsed passages become pods of chaotic breccia (Fig. 3). The areal cross-sectional extent of brecciation and fracturing after burial and collapse is greater than that of the original passage because the adjacent fractured and brecciated host rock has become part of the brecciated pod. Sag features, faults, and fractures (Fig. 3) occur over the collapsed passages.

\section{EVOLUTION OF COALESCED, COLLAPSED-PALEOCAVE SYSTEMS}

A coalesced, collapsed-paleocave system can be divided into two parts: (1) a lower section of strata that contains collapsed paleocaves and (2) an upper section of strata that is deformed to varying degrees by the collapse and compaction of the section of paleocave-bearing strata (Fig. 5). The deformed upper section of strata is termed suprastratal deformation (Loucks, 2003) and is discussed in a later section.

Cave systems are composed of numerous passages. If the areal density of passages is low, the collapsed cave system will feature isolated, collapsed passages (noncoalescing paleocave system; Fig. 6). If the cave system has a high density of passages, as is common at composite third-order unconformities (Esteban, 1991; Lucia, 1995;

Fig. 6: Schematic diagram showing burial and collapse of lowdensity cave system (noncoalescing, collapsed-cave system) and reprinted by permission of the AAPG whose permission is required for further use."

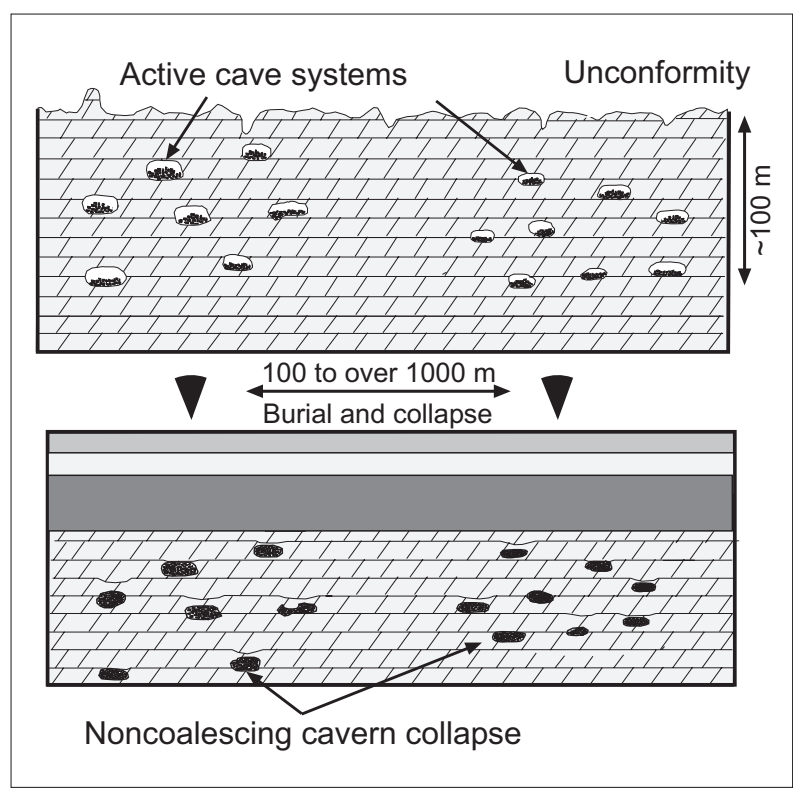




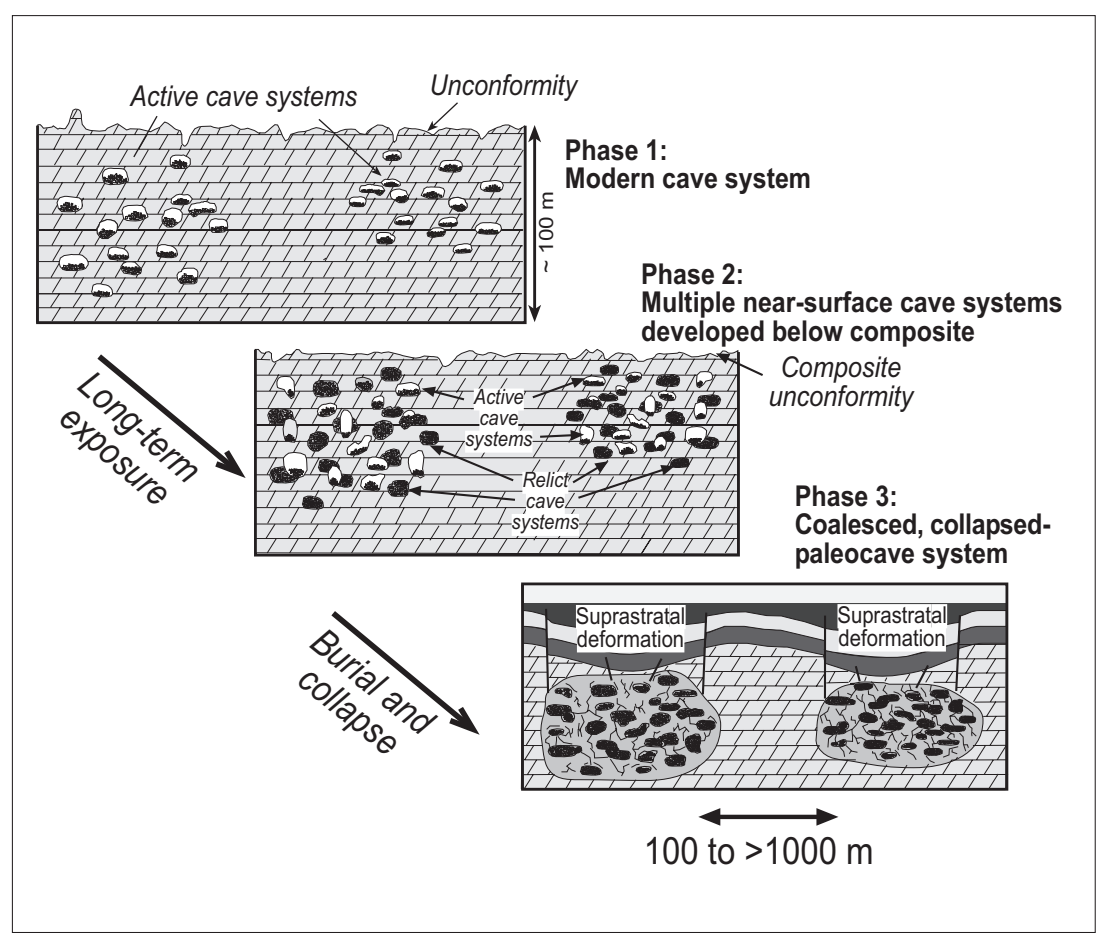

Loucks, 1999), then upon burial and collapse the system can form largescale, coalesced, brecciated and fractured breccia bodies upon burial and collapse that are the amalgamation of many passages and intervening disturbed host rock (coalescing paleocave system; Fig. 5). The bodies are hundreds to several thousands of meters across, thousands of meters long, and tens of meters to more than $100 \mathrm{~m}$ thick. Internal spatial complexity is high, resulting from the collapse and coalescence of numerous passages and cave-wall and cave-ceiling strata.

Fig. 5: Schematic diagram showing the stages of development of a coalesced, collapsed-paleocave system. Modified from Loucks et al., (2004) and reprinted by permission of the AAPG whose permission is required for further use."

\section{SUPRASTRATAL DEFORMATION}

Collapse and compaction of cave systems provide potential for development of large-scale fracture/fault systems that can extend from the collapsed interval upward to more than 700 m (Kerans, 1990; Hardage et al., 1996a; Loucks, 1999, 2003; McDonnell et al., in press). These fracture/fault systems are not related to regional tectonic stresses.

Large-scale suprastratal deformation occurs above the collapsed-cave system. As the cave system collapses during burial, overlying strata will sag or subside over the collapsed area. This phenomenon is well documented in mining literature (Kratzsch, 1983; Wittaker and Reddish, 1989). Kratzsch (1983, p. 147) presented a diagram (Fig. 7) that shows the stress field above a collapsed mine passage and associated subsidence. The overlying stress field widens from the edges of the excavation, and the overlying strata are under compression directly over the excavation. Near the edges of the excavation, between a vertical line extending from the edge of the cavity and the limit line, strata are under extension (tension). Within this zone of stress the overlying strata have the potential to sag, creating faults and fractures for some distance upward, depending on the mechanical properties of the strata and the thickness of the beds within the strata. Fig. 8 is a scatterplot showing a number of examples of the magnitude of subsidence over coal mines. The graph indicates that subsidence is recorded at horizons more than $800 \mathrm{~m}$ above the cavity. These data indicate the magnitude of the effect that the collapse of a cavity can have on overlying strata.

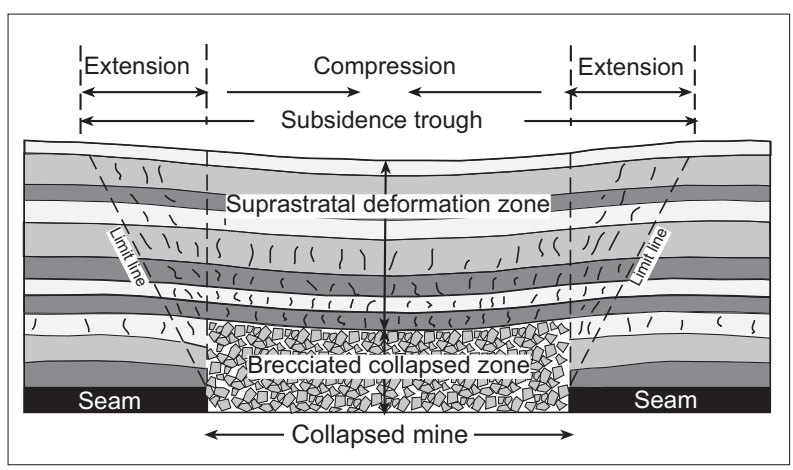

Fig. 7: Diagram of a collapsed mine showing collapsed breccia zone and suprastratal deformation. The center of the subsidence trough is under compression, whereas the wings are under extension. Modified from Kratzch (1983).

Applying the above concept of stress fields over cavities to the collapse of a cave passage during burial sug- 
gests that similar stress fields will develop. As the cave passage collapses, it has the potential to affect a consider-

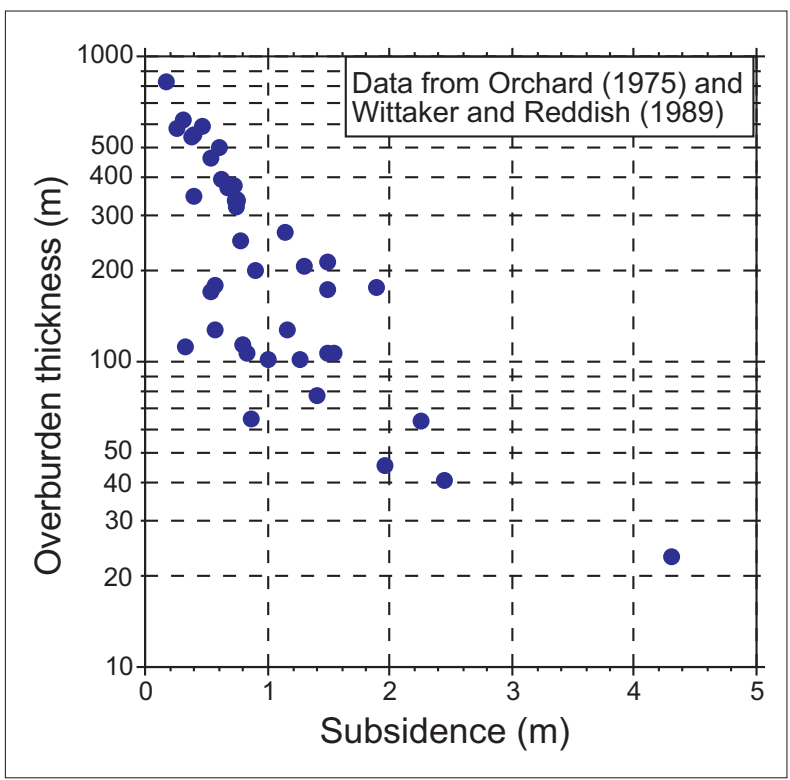

able number of overlying strata. Within a cave system, numerous passages will collapse with burial. Each passage will develop a stress field above it, and these stress fields will interact to create a larger, combined stress field. This concept was presented by Wittaker and Reddish (1989; p. 47), who detailed instances in which multiple mining excavations are collapsing. The stress field above a collapsing cave system will be complex because the different cave passages do not collapse and compact uniformly over time. As local areas collapse, different stress fields will develop, producing fractures and faults related to that individual stress field. Resulting suprastratal deformation will show variable fracture and fault patterns within an overall subsidence sag. A unique circular fault pattern above collapsed cave systems is recognized by cylindrical faults (Hardage et al., 1996a; Loucks, 1999; McDonnell et al., in press).

Fig. 8: Scatterplot showing thickness of overburden that can be affected by mine collapse. Graph shows a trend of greater subsidence with less overburden.

\section{MEGASCALE ARCHITECTURE PATTERNS OF COALESCED, COLLAPSED-PALEOCAVE SYSTEMS}

Coalesced, collapsed-paleocave systems are megascale diagenetic/structural features that can affect more than $700 \mathrm{~m}$ of section and be regional in scale. As discussed earlier, the karsted section reflects the coalescing of collapsed breccias that formed by collapse of passages and associated disturbed host rock. The vertical extent of the breccias commonly affects the upper $100 \mathrm{~m}$ of section (Loucks and Handford, 1992; Loucks 1999) and as much as $300 \mathrm{~m}$ of the total section (Lucia, 1996). The intensity of brecciation can vary throughout the affected interval. Kerans (1990), Loucks (1999), Loucks et al., 2004), and many others have published descriptions of collapsed, brecciated paleocave zones. Fig. 9 shows examples of cave facies from the Lower Ordovician Ellenburger Group in central Texas (Loucks et al., 2004).

The regional pattern of the collapsed paleocave system is commonly rectilinear (Loucks, 1999). This rectilinear pattern is probably an artifact of the original cave system developing along an early-formed fracture system. In a detailed study of a paleocave system in the

Fig. 10: Slice map through a collapsed-paleocave system in the Lower Ordovician Ellenburger Group in central Texas. Modified from Loucks (2004) and reprinted by permission of the AAPG whose permission is required for further use."

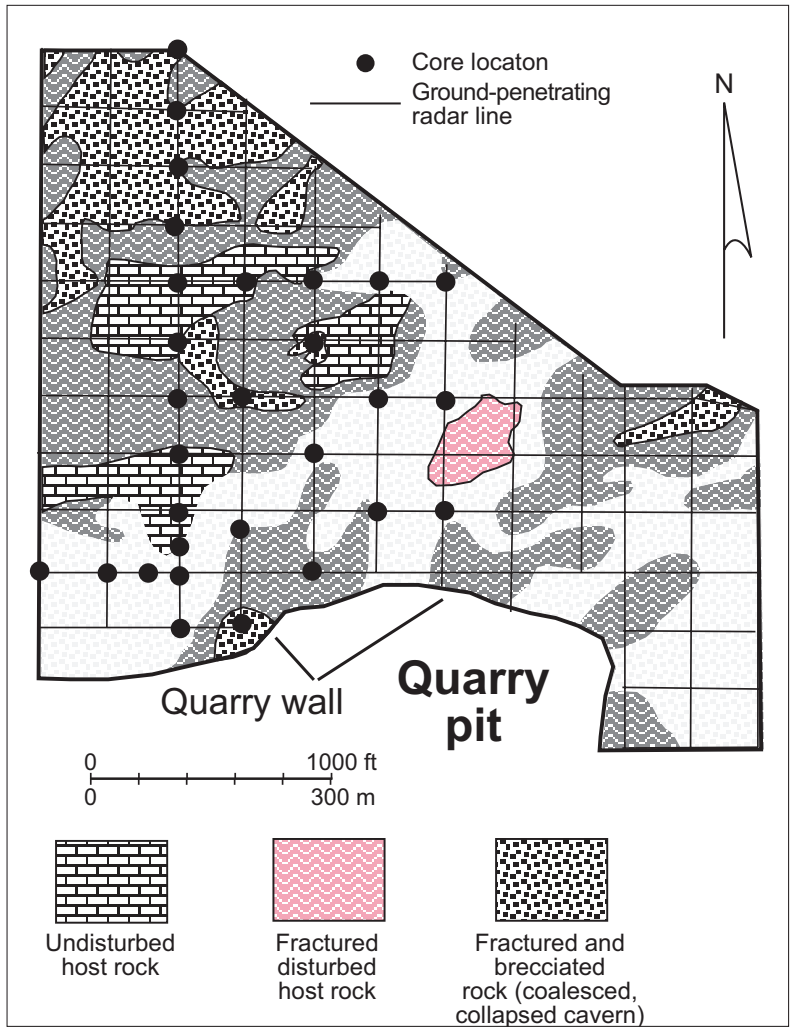


Lower Ordovician in central Texas, Loucks et al. (2004) presented maps (Fig. 10) and cross sections of the threedimensional, fine-scale architecture of a coalesced, collapsed-paleocave system. The coalesced, collapsed-passage breccias range in size to as much as $350 \mathrm{~m}$ and are separated by disturbed and undisturbed host rock ranging in size up to $200 \mathrm{~m}$. Lucia (1995) also presented a map of brecciated collapsed passages (Fig. 11) from outcrops in the Franklin Mountains of far west Texas, which displays a crude rectilinear pattern.

This rectilinear pattern can be seen on seismic data as well. Loucks (1999) presented seismic-based maps from Benedum field in West Texas that display a rectilinear pattern of sags and circular faults induced by collapse of the Ellenburger paleocave system below (Fig. 12). A similar rectilinear pattern is evidenced on seismic data in Boonsville field (Fig. 13) in the northern Fort Worth Basin in Texas (Hardage et al., 1996a; McDonnell et al., in press). In both the Benedum and Boonesville datasets, suprastratal deformation affects up to $700 \mathrm{~m}$ of section above the karsted interval (Figs. 12 and 13).

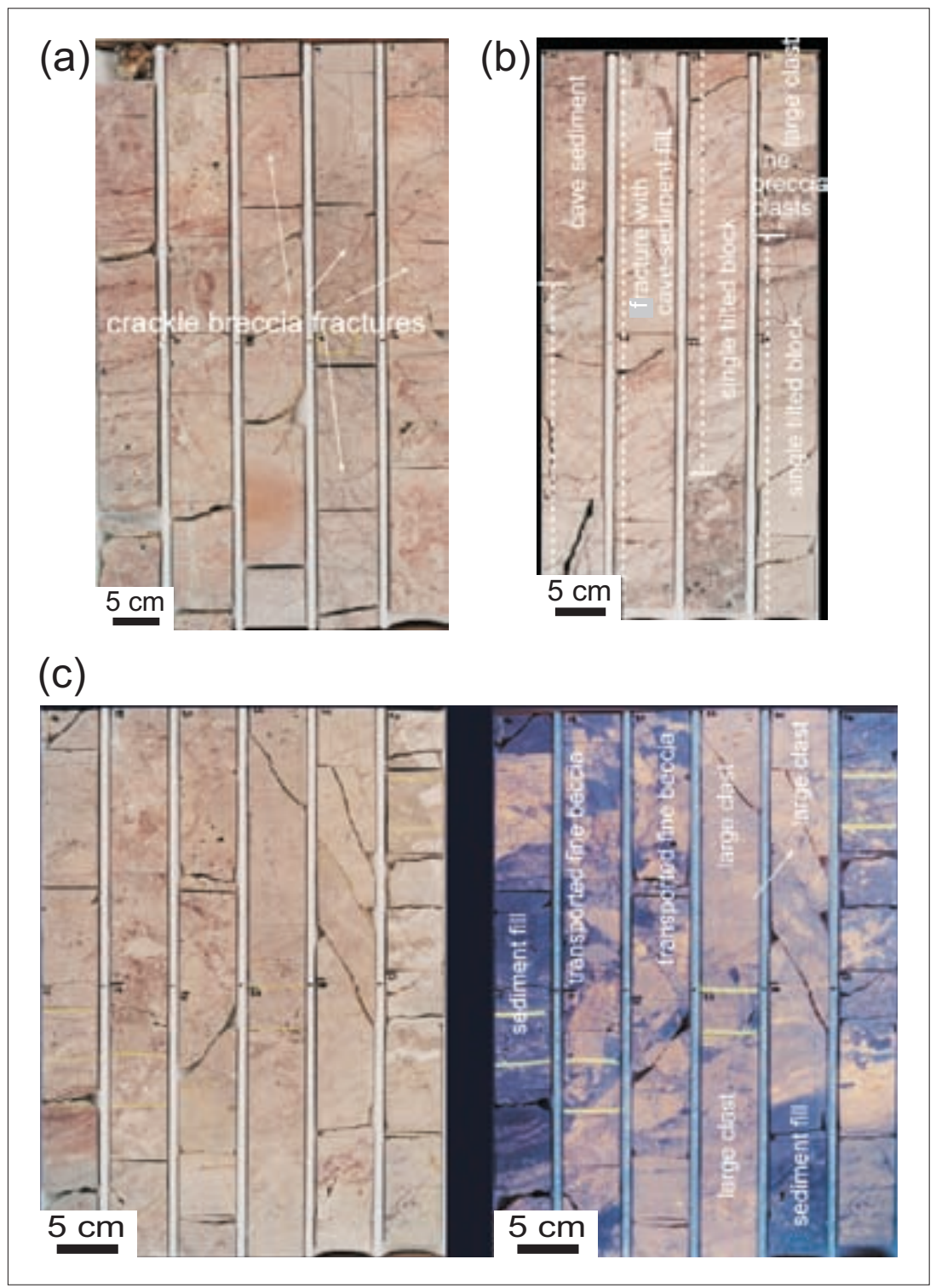

Fig. 9: Representative cores from paleocave facies. (a) Crackle-fractured disturbed host rock. (b) Collapsed chaotic breccia with large slabs and cave-sediment fill. (c) Transported chaotic breccias in carbonate cave-fill matrix. Sample on right is under UV light. Samples from Lower Ordovician Ellenburger Group in central Texas. Modified from Loucks (2004) and reprinted by permission of the AAPG whose permission is required for further use." 


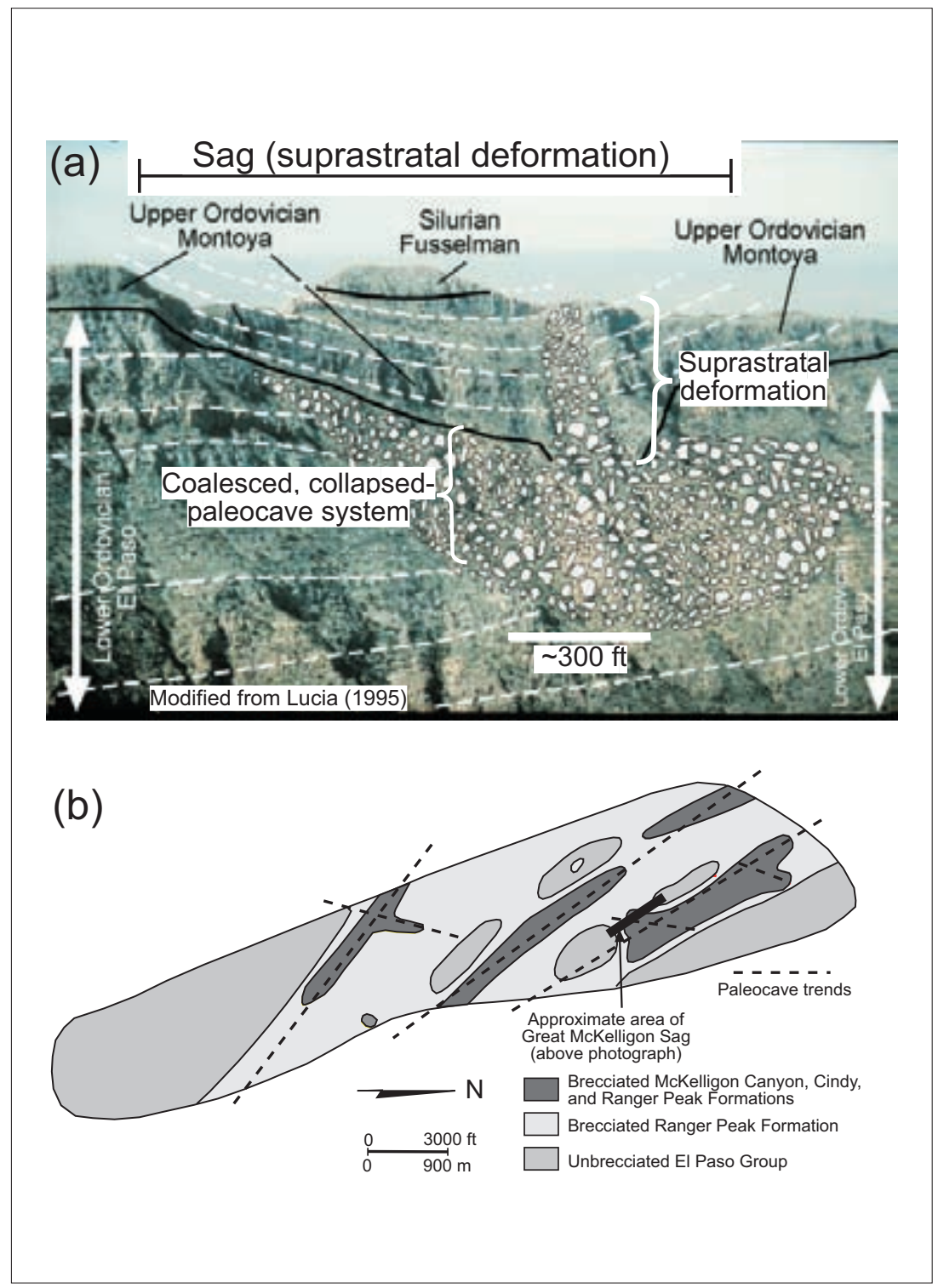

Fig. 11: (a) Photograph of the Great McKelligon Sag in the Franklin Mountains of far West Texas. Photograph and general interpretation are from Lucia (1995) but have been modified by current author. This outcrop is an outstanding example of a collapsedpaleocave system with associated overlying suprastratal deformation. (b) Map produced by Lucia (1995) of several paleocave systems within the Franklin Mountains. Paleocave trend lines are by current author.

\section{CONCLUSIONS}

Coalesced, collapsed-paleocave systems are megascale diagenetic/structural features that can affect more than $700 \mathrm{~m}$ of section and be regional in scale. The architecture of the complete system can be divided into the lower collapsed zone, where the dense system of caves formed and collapsed with later burial, producing a complex zone of brecciation. The upper, suprastratal deformation section formed during the collapse of the karsted section.
The overlying strata were generally lithified, but the sag also affected concurrent sedimentation patterns (Hardage et al., 1996b). The deformation in the deformed suprastratal zone consists of normal, reverse, and cylindrical faults and fractures (Loucks, 1999; McDonnell et al., in press). It is important to emphasize that large-scale structural features can develop above karsted zones and not be related to regional tectonic stresses. 


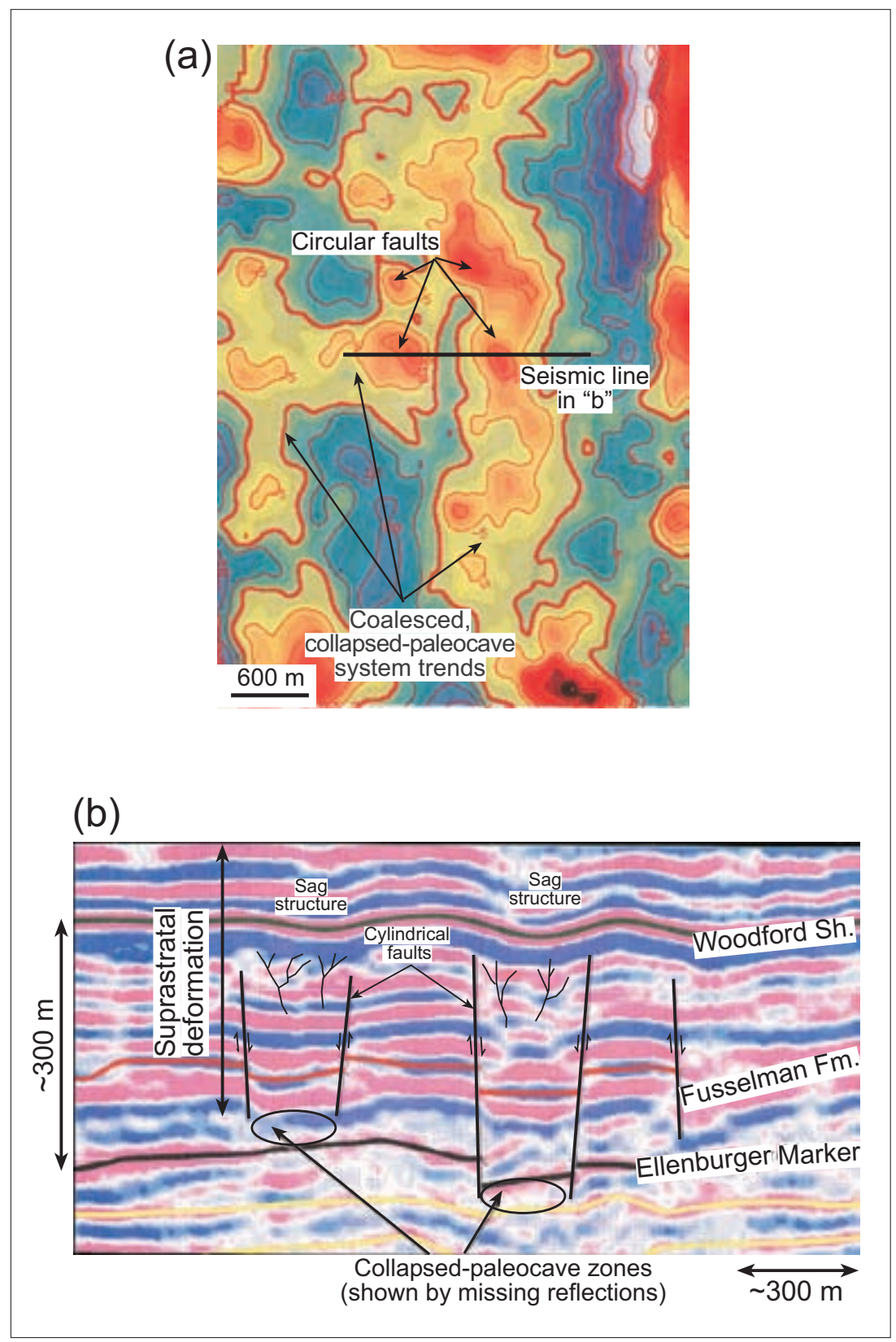

Fig. 12: 3-D seismic example over an Ellenburger paleocave system from Benedum field in West Texas. (a) Second-order derivative map in the Fusselman interval displaying sag zones produced by Ellenburger paleocave collapse. (b) Seismic line showing missing sections (collapse in Ellenburger section), cylindrical faults, and sag structures. Suprastratal deformation is $>1,000 \mathrm{ft}$ thick in this section. Modified from Loucks (1999) and reprinted by permission of the AAPG whose permission is required for further use."

Coalesced, collapsed-paleocave systems and associated suprastratal deformation are complex systems, and large-scale outcrops or datasets are necessary to define them. However, with the model presented in this paper, individual data points can lead to recognition that the system is a coalesced, collapsed-paleocave feature. 
(a)
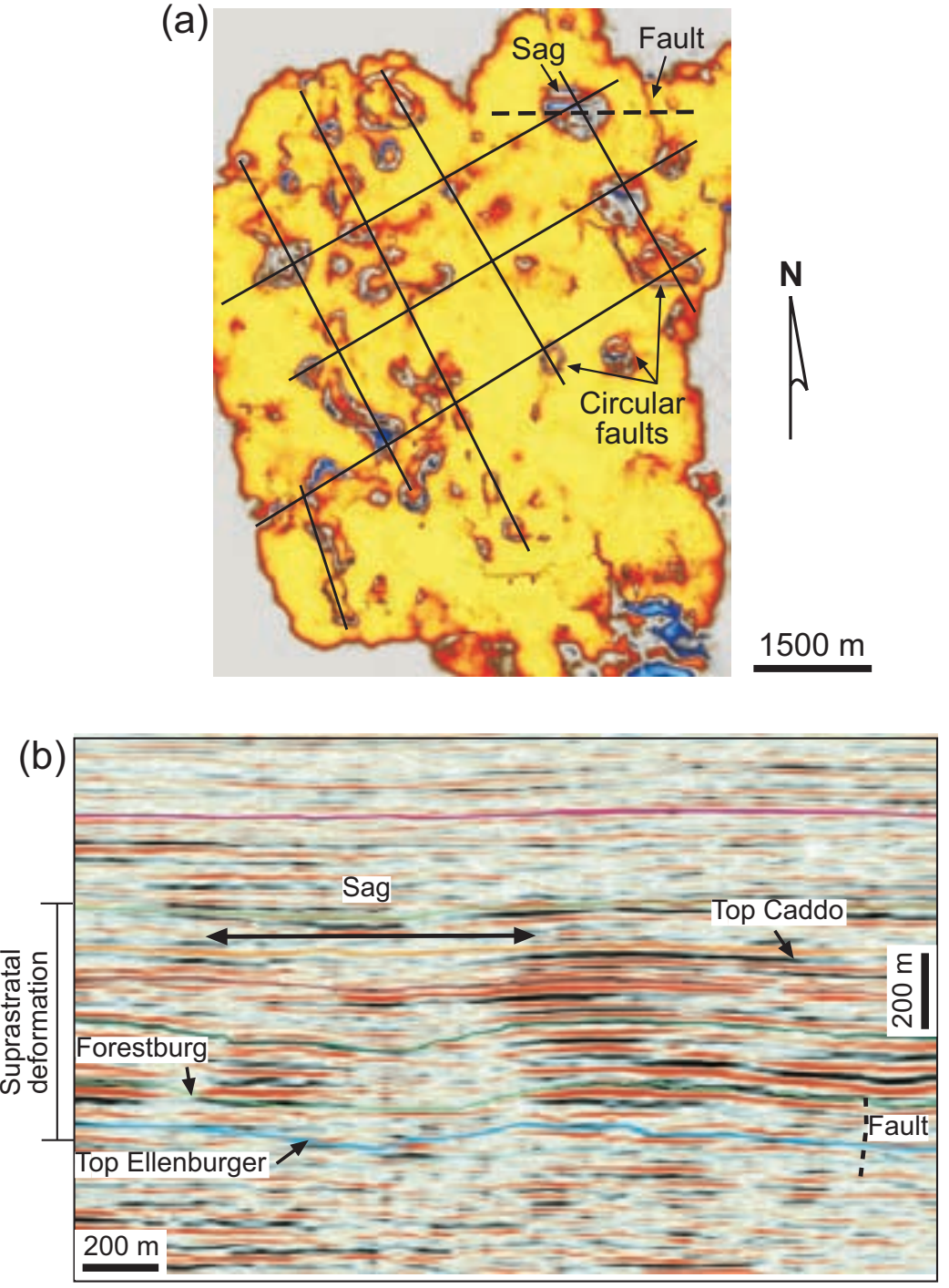

Fig. 13: Suprastratal deformation sag features in post-Lower Ordovician Ellenburger strata in Fort Worth Basin in north Texas. (a) Curvature map at Mississippian Forestburg Limestone horizon displaying sag features and faults produced by collapse in the Ellenburger interval. From McDonnell et al. (in press). (b) 3D seismic line at 1:1 scale showing sag features produced by paleocave collapse in the Ellenburger section. Line-of-section location is shown by dashed line in Fig. 13a.

\section{ACKNOWLEDGEMENTS}

I would like to express my appreciation to Angela McDonnell for reviewing this manuscript. Lana Deiterich edited the text. Published with the permission of the Di- rector, Bureau of Economic Geology, John A. and Katherine G. Jackson School of Geosciences, The University of Texas at Austin. 


\section{REFERENCES}

Candelaria, M. P. \& C. L. Reed, eds., 1992: Paleokarst, karst related diagenesis and reservoir development: examples from Ordovician-Devonian age strata of West Texas and the Mid-Continent.- Permian Basin Section SEPM Publication No. 92-33, p. 202.

Combs, D. M., R. G. Loucks, \& S. C. Ruppel, 2003: Lower Ordovician Ellenburger Group collapsed paleocave facies and associated pore network in the Barnhart field, Texas.- in T. J. Hunt \& P. H. Lufholm, The Permian Basin: back to basics: West Texas Geological Society Fall Symposium: West Texas Geological Society Publication No. 03-112, 397-418.

Ford, D. C., 1988: Characteristics of dissolutional cave systems in carbonate rocks.- in N. P. James \& P. W. Choquette, eds., Paleokarst: Springer-Verlag, Berlin, 25-57.

Esteban, M., 1991: Palaeokarst: practical applications.- in V. P. Wright, M. Esteban, \& P. L. Smart, eds., Palaeokarst and palaeokarstic reservoirs: University of Reading, Postgraduate Research for Sedimentology, PRIS Contribution No. 152, 89-119.

Hammes, Ursula, F. J. Lucia, \& Charles Kerans, 1996: Reservoir heterogeneity in karst-related reservoirs: Lower Ordovician Ellenburger Group, West Texas.in E. L. Stoudt, ed., Precambrian-Devonian geology of the Franklin Mountains, West Texas-analogs for exploration and production in Ordovician and Silurian karsted reservoirs in the Permian Basin: West Texas Geological Society, Publication No. 96-100, 99-117.

Hardage, B. A., D. L. Carr, D. E. Lancaster, J. L. Simmons Jr., R. Y. Elphick, V. M. Pendleton, \& R. A. Johns, 1996a: 3-D seismic evidence of the effects of carbonate karst collapse on overlying clastic stratigraphy and reservoir compartmentalization.- Geophysics, 61, 1336-1350.

Hardage, B. A., D. L. Carr, D. E. Lancaster, J. L. Simmons, Jr., D. S. Hamilton, R. Y. Elphick, K. L. Oliver, \& R. A. Johns, 1996b: 3-D seismic imaging and seismic attribute analysis of genetic sequences deposited in low-accommodation conditions.- Geophysics, 61, 1351-1362.

Kerans, Charles, 1988: Karst-controlled reservoir heterogeneity in Ellenburger Group carbonates of West Texas.- reply: American Association of Petroleum Geologists Bulletin, 72, p. 1160-1183.

Kerans, Charles, 1989: Karst-controlled reservoir heterogeneity and an example from the Ellenburger Group (Lower Ordovician) of West Texas.- The University of Texas at Austin, Bureau of Economic Geology Report of Investigations No. 186, p. 40.
Kerans, Charles, 1990: Depositional systems and karst geology of the Ellenburger Group (Lower Ordovician), subsurface West Texas.- The University of Texas at Austin, Bureau of Economic Geology Report of Investigations No. 193, p. 63.

Kerans, Charles, F. J. Lucia, \& R. K. Senger, 1994: Integrated characterization of carbonate ramp reservoirs using Permian San Andres outcrop analogs.American Association of Petroleum Geologists Bulletin, 78, 181-216.

Kratzsch, H., 1983: Mining Subsidence Engineering.Springer-Verlag, Berlin, Translated by R. F. S. Fleming, p. 543.

Loucks, R. G., 1999: Paleocave carbonate reservoirs: origins, burial-depth modifications, spatial complexity, and reservoir implications.- American Association of Petroleum Geologists Bulletin, 83, 1795-1834.

Loucks, R. G., 2001: Modern analogs for paleocave-sediment fills and their importance in identifying paleocave reservoirs.- Gulf Coast Association of Geological Societies Transactions, 46, 195-206.

Loucks, R. G., 2003: Understanding the development of breccias and fractures in Ordovician carbonate reservoirs.- in T. J. Hunt \& P. H. Lufholm, The Permian Basin: back to basics: West Texas Geological Society Fall Symposium: West Texas Geological Society Publication No. 03-112, 231-252.

Loucks, R. G. \& J. H. Anderson, 1980: Depositional facies and porosity development in Lower Ordovician Ellenburger dolomite, Puckett Field, Pecos County, Texas.- in R. B. Halley \& R. G. Loucks, eds., Carbonate reservoir rocks: SEPM Core Workshop No. $1,1-31$.

Loucks, R. G. \& J. H. Anderson: 1985, Depositional facies, diagenetic terrains, and porosity development in Lower Ordovician Ellenburger Dolomite, Puckett Field, West Texas.- in P. O. Roehl \& P. W. Choquette, eds., Carbonate petroleum reservoirs: Springer-Verlag, 19-38.

Loucks, R. G. \& R. H. Handford, 1992: Origin and recognition of fractures, breccias, and sediment fills in paleocave-reservoir networks.- in M. P. Candelaria \& C. L. Reed, eds., Paleokarst, karst related diagenesis and reservoir development: examples from Ordovician-Devonian age strata of West Texas and the Mid-Continent: Permian Basin Section SEPM Publication No. 92-33, 31-44. 
Loucks, R. G. \& P. Mescher, 2001: Paleocave facies classification and associated pore types.- American Association of Petroleum Geologists, Southwest Section, Annual Meeting, Dallas, Texas, March 11-13, CD-ROM, p.18.

Loucks, R. G., P. Mescher, \& G. A. McMechan, 2000: Architecture of a coalesced, collapsed-paleocave system in the Lower Ordovician Ellenburger Group, Dean Word Quarry, Marble Falls, Texas.- Final report prepared for the Gas Research Institute, GRI00/0122, CD-ROM.

Loucks, R. G., P. Mescher, \& G. A. McMechan, 2004: Three-dimensional architecture of a coalesced, collapsed-paleocave system in the Lower Ordovician Ellenburger Group, Central Texas.- American Association of Petroleum Geologists Bulletin, 88, 545564.

Lucia, F. J., 1968: Sedimentation and paleogeography of the El Paso Group.- in W. J. Stewart, ed., Delaware basin exploration: West Texas Geological Society Guidebook No. 68-55, 61-75.

Lucia, F. J., 1995: Lower Paleozoic cavern development, collapse, and dolomitization, Franklin Mountains, El Paso, Texas.- in D. A. Budd, A. H. Saller, and P. M. Harris, eds., Unconformities and porosity in carbonate strata: American Association of Petroleum Geologists Memoir 63, 279-300.

Lucia, F. J., 1996: Structural and fracture implications of Franklin Mountains collapse brecciation.- in E. L. Stoudt, ed., Precambrian-Devonian geology of the Franklin Mountains, West Texas-Analogs for exploration and production in Ordovician and Silurian karsted reservoirs in the Permian basin: West Texas Geological Society 1996 Annual Field Trip Guidebook, WTGS Publication No. 96-100, 117-123.

Lucia, F. J., Charles Kerans, \& G. W. Vander Stoep, 1992 Characterization of a karsted, high-energy, rampmargin carbonate reservoir: Taylor-Link West San Andres Unit, Pecos County, Texas.- The University of Texas at Austin, Bureau of Economic Geology Report of Investigations No. 208, p. 46.

Mazzullo, S. J. \& G. V. Chilingarian, 1996: Hydrocarbon reservoirs in karsted carbonate rocks.- in G. V. Chilingarian, S. J. Mazzullo, \& H. H. Rieke, eds., Carbonate reservoir characterization: a geologic-engineering analysis, Part II: Elsevier, 797-685.
McDonnell, A., R.G. Loucks, \& T. Dooley, (in press): Quantifying the origin and geometry of circular sag structures in northern Fort Worth Basin, Texas: paleocave collapse, pull-apart fault systems or hydrothermal alteration?.- American Association of Petroleum Geologists Bulletin.

McMechan, G. A., R. G. Loucks, P. A. Mescher, \& Xiaoxian Zeng, 2002: Characterization of a coalesced, collapsed paleocave reservoir analog using GPR and well-core data.- Geophysics, 67, 1148-1158.

McMechan, G. A., R. G. Loucks, X. Zeng, \& P. A., Mescher, 1998: Ground penetrating radar imaging of a collapsed paleocave system in the Ellenburger dolomite, Central Texas.- Journal of Applied Geophysics, 39, 1-10.

Orchard, R. J., 1975: Prediction of the magnitude of surface movements.- in Proceedings, European Congress on Ground Movement, 39-46.

Palmer, A. N., 1991: Origin and morphology of limestone caves.- Geological Society of America Bulletin, 103, $1-21$.

White, W. B., 1988: Geomorphology and hydrology of karst terrains.- Oxford University Press, New York, p. 464.

Wilson, J. L., R. L. Medlock, R. D. Fritz, K. L. Canter, \& R. G. Geesaman, 1992: A review of Cambro-Orodovician breccias in North America.- in M. P. Candelaria \& C. L. Reed, eds., Paleokarst, karst related diagenesis and reservoir development: examples from Ordovician-Devonian age strata of West Texas and the Mid-Continent: Permian Basin Section SEPM Publication No. 92-33, 19-29.

Wittaker, B. N. \& D. J. Reddish, 1989: Subsidence; Occurrence, Prediction and Control: Elsevier, Development in Geotechnical Engineering, No. 56, p.528.

Wright, V. P., M. Esteban, \& P. L. Smart, eds., 1991: Palaeokarst and palaeokarstic reservoirs: Postgraduate Research for Sedimentology, University, PRIS Contribution No. 152, p.158. 